\title{
Fructans and Water Suppression on Intact and Fragmented Rhizophores of Vernonia herbacea
}

\author{
Gláucia M. Dias-Tagliacozzo ${ }^{1 *}$, Nair M. Itaya ${ }^{2}$, M. Angela Machado de Carvalho $^{2}$, Rita de \\ Cássia L. Figueiredo-Ribeiro ${ }^{2}$ and Sonia M. C. Dietrich ${ }^{2}$ \\ ${ }^{1}$ Instituto Agronômico de Campinas; Centro de Horticultura; C. P. 28; 13001-970; Campinas - SP - Brazil. ${ }^{2}$ Seção \\ de Fisiologia e Bioquímica de Plantas; Instituto de Botânica de São Paulo; C. P. 4005; 01061-970; São Paulo - SP \\ - Brazil
}

\begin{abstract}
In order to evaluate the involvement of fructans in drought tolerance, experiments were conducted using intact plants and excised rhizophores of Vernonia herbacea. The water content in rhizophores of intact plants was maintained for 30 days when plants were watered every 7 and 15 days, whereas plants remained alive up to 60 days without water. Total fructan, oligo- to polysaccharides ratio and mean molecular mass of polysaccharides increased in these plants indicating depolymerization of median size molecules. In apical fragments of rhizophores kept dry the oligosaccharides increased in relation to polysaccharides one day after excision in treated tissues. This was reflected in the HPLC profile of the oligosaccharides in which the proportion of free fructose and fructans with DP 4-10 increased markedly. Results indicate that fructan metabolism is involved in drought tolerance of $\mathrm{V}$. herbacea.
\end{abstract}

Key words: Inulin, environmental stresses, drought, fructan metabolism, reserve organs, Asteraceae

\section{INTRODUCTION}

Fructans are the main reserve carbohydrate in the highly evolved and economically important plant families Poaceae and Asteraceae. So far their physiological role, besides being a reserve carbohydrate, remains unclear. As fructans are synthesized from sucrose in the vacuoles (Wagner et al., 1983; Vijn et al., 1997), their synthesis might control the sucrose concentration in this cell compartment, therefore preventing sugar-induced feedback inhibition of photosynthesis (Pollock, 1986 and references therein).

Several authors have studied the role of fructans as cryoprotectant, conferring survival under low temperatures (Eagles, 1967; Pontis and Del
Campillo, 1985; Wiemken et al., 1986; Puebla et al. 1997). It has been suggested that fructans play a primary role as an osmotic regulator, allowing not just survival of the plants but growth under conditions of limited access to water (Spollen and Nelson, 1994; Pilon-Smits et al., 1995). The theories of low temperature survival and osmotic regulation come together in one aspect, the seasonality of plant growth (Hendry and Wallace, 1993). Fructan containing species are most abundant in areas where growth is concentrated in certain seasons within an annual cycle, for example in regions showing a seasonal pattern of rainfall. Evidences for the involvement of fructans in drought tolerance, either directly or indirectly through their depolymerization to sucrose and

\footnotetext{
* Author for correspondence
} 
hexoses, compounds osmotically more active than fructans, have been reported by various authors. Spollen and Nelson (1994) studied the effect of water deficit in leaves of tall fescue and showed that the involvement of fructan metabolism in osmotic adjustment was indirect and that sucrose and hexoses were the effective compounds to lower the osmotic potential of the cells. PilonSmits et al. (1995) introduced a bacterial enzyme capable of synthesizing fructans into tobacco plants, a non-fructan species. These fructanproducing transgenic plants showed more resistance to drought stress, as determined by their biomass accumulation. Recently, similar results were obtained with transformed sugar beets (PilonSmits et al., 1999). However, as information concerning fructan mediated drought tolerance in transgenic plants was obtained with the introduction of a bacterial enzyme, it could be controversial among plant physiologists.

Vernonia herbacea (Asteraceae) is native to the cerrado vegetation and presents a well defined seasonal pattern of growth within the annual cycle (Carvalho and Dietrich, 1993; Carvalho et al., 1997). Similar to various other herbaceous Asteraceae from the cerrado (Tertuliano and Figueiredo-Ribeiro, 1993), plants of this species accumulate high levels of fructans of the inulin type in the underground storage organs (Carvalho and Dietrich, 1993). These organs, named rhizophores (Menezes et al., 1979), guarantee the perenation of the plants during unfavourable periods of drought in the cerrado, which coincide with the low temperatures of winter.

Dias-Tagliacozzo et al. (1999) have shown that low temperatures have no direct effect on fructan metabolism in intact plants nor in fragmented rhizophores of $V$. herbacea. The authors suggested that differences observed in fructan contents and in the proportion of the individual members of the homologous fructan series were due mostly to changes imposed by low temperatures on the rates of metabolic processes characteristic of the phenological stages of the plants at the moment the experiments were performed. Based on these results our attention has been focused on the effect of water suppression on fructan metabolism and consequently on the possible involvement of these compounds in the resistance of $V$. herbacea to drought.

\section{MATERIAL AND METHODS}

\section{Plant material and experimental descriptions}

Plants of Vernonia herbacea (Vell.) Rusby were collected from a preserved cerrado area in MojiGuaçu, SP, Brazil $\left(22^{\circ} 18^{\prime} \mathrm{S}, 47^{\circ} 11^{\prime} \mathrm{W}\right)$ and used directly to obtain rhizophore apices or as propagation material for new plants. Two year old plants obtained from rhizophore fragments through vegetative propagation were used in the experiment. Plants were cultivated in individual pots (2.0 L capacity), separated into 5 groups, each one receiving a different watering regime: 1) control plants, soil under $100 \%$ field capacity; 2) plants irrigated every 7 days; 3 ) plants irrigated every 15 days; 4) plants irrigated every 30 days and 5) plants kept dry for 60 days. Sampling days for analyses were of 30 (plants from group 2, 3 and 4) and of 60 days (plants from group 2, 3, 4 and 5). The experiment was carried out from September through November 1992 in a greenhouse, with averages of low and high temperatures of 20 and $35^{\circ} \mathrm{C}$, respectively.

In another experiment, apical fragments of rhizophores measuring $1.5 \mathrm{~cm}$ in length were obtained from plants collected during the summer and placed in Petri dishes layered with filter paper. Water was added to half of the dishes while the other half was maintained dry. The experiment was carried out in growth chambers at $20^{\circ} \mathrm{C}$, in the dark. Fragments from both treatments were analysed for soluble carbohydrates and water contents 1, 3, 5 and 7 days from the beginning of the experiment. On day five, fragments which had been kept dry were watered to allow tissue rehydration. On each sampling day, fragments were collected from the Petri dishes, frozen and freezedried before analysis. The same samples were used for dry mass determination.

Field capacity was determined by the difference in mass between wet and dry soils. Drying was obtained under $105{ }^{\circ} \mathrm{C}$. On each sampling day the soils were dried, weighed and their water content was calculated as a percentage of the field capacity. Relative water content in rhizophores was calculated as described by Thomas (1991):

$$
\mathrm{RWC}=\frac{100 \mathrm{X} \text { weight of water in fresh tissue }}{\text { weight of water in fully hydrated tissue }}
$$

Leaf area was calculated by using a linear regression curve $(y=0.2737+0.7158 x)$, where $x$ is the product of leaf length vs. leaf width, with a 
correlation coefficient of 0.9658 , determined specifically for this species (Carvalho, 1991). Dry mass of rhizophores was determined in samples by oven drying at $80{ }^{\circ} \mathrm{C}$ to constant weight. The above measurements were done in five samples, each one represented by one potted plant.

\section{Carbohydrate extraction and analysis}

Fructans were extracted from three separate samples according to Pollock and Jones (1979). The tissue was ground in a mortar with $80 \%$ aqueous ethanol and the homogenate placed in a water bath at $80{ }^{\circ} \mathrm{C}$ for $5 \mathrm{~min}$ and centrifuged at $1,000 \mathrm{~g}$ for $15 \mathrm{~min}$. The residue was reextracted once as above and then submitted to water extraction for $30 \mathrm{~min}$ at $60{ }^{\circ} \mathrm{C}$. The supernatants were pooled and concentrated. Following, three volumes of ethanol were added to allow precipitation of the fructo-polysaccharides present in the mixture. Remaining supernatant contained the fructo-oligosaccharides.

Free and combined fructose were measured using a kestose specific modification of the anthrone reaction (Jermyn, 1956) and fructose as standard. Fructo-oligosaccharides were deionized through ion exchange columns, according to Carvalho and Dietrich (1993). Subsequently they were analysed by high performance thin-layer chromatography (TLC) on silica gel plates according to Kanaya et al. (1978) and stained with urea-phosphoric acid (Wise et al., 1955). Oligosaccharides of the inulin series from tubers of Helianthus tuberosus were used as standards.

Fructans were also analysed on a PA-1 anion exchange column using a Dionex DX-300 gradient chromatography system with pulsed amperometric detection (HPAEC/PAD). The gradient was established according to Shiomi (1993). Eluent A $(150 \mathrm{mM} \mathrm{NaOH})$ and eluent $\mathrm{B}(500 \mathrm{mM}$ sodium acetate in $150 \mathrm{mM} \mathrm{NaOH}$ ) were mixed as follows: 0-1min., 25mM; 1-2min., 25-50mM; 2-14min., 50500mM; 14-22min., 500mM; 22-30min., 25mM. The flow rate through the column was $1 \mathrm{~cm}^{3} \cdot \mathrm{min}^{-1}$. The applied PAD potentials for E1 $(300 \mathrm{~ms})$, E2 $(120 \mathrm{~ms})$ and E3 (300 ms) were $0.05,0.60$ and $-0.60 \mathrm{~V}$, respectively, and the output range was $1 \mathrm{nA}$.

HPAEC/PAD elution patterns were compared to those of reference standards obtained from tubers of $H$. tuberosus extracted according to Pollock and Jones (1979).

Fructo-polysaccharides were analysed by gel permeation chromatography (GPC) using a BioGel P-10 column as described by Carvalho and Dietrich (1993). Relative molecular mass was estimated according to Andrews (1965).

\section{RESULTS}

Rhizophores of intact plants maintained a relative water content near $100 \%$ for 60 days when water was supplied every 7 and 15 days. Plants, from which water was withheld for 30 days also maintained this high level of water contents during the first 30 days, but failed to keep it for 60 days. Water in soil gradually decreased in all watering frequencies (Fig. 1).

Thirty days after the beginning of the treatments, total fructan increased in plants from which water was withheld for 30 days as a result of an increase in both oligo- and polysaccharide fractions whereas no significant changes were observed in plants watered every 7 or 15 days. However, after 60 days, fructo-polysaccharides decreased in all watering frequency treatments, causing an increase in the ratio of oligo- to polysaccharides mainly in plants irrigated every 15 and 30 days (Fig. 2).

Qualitative analysis of fructo-oligosaccharides by TLC (Fig. 3) showed that every low DP members of the inulin series (DP 3 - ca. 14) was present in this fraction, although changes in their relative proportions were observed for the various treatments. In plants watered every 30 days, fructose, sucrose and the remaining components of the series were more concentrated, reflecting the observed increase of total fructose in the oligosaccharide fraction. This increase occurred simultaneously to the reduction in the polysaccharide fraction seen in Fig. 2. 


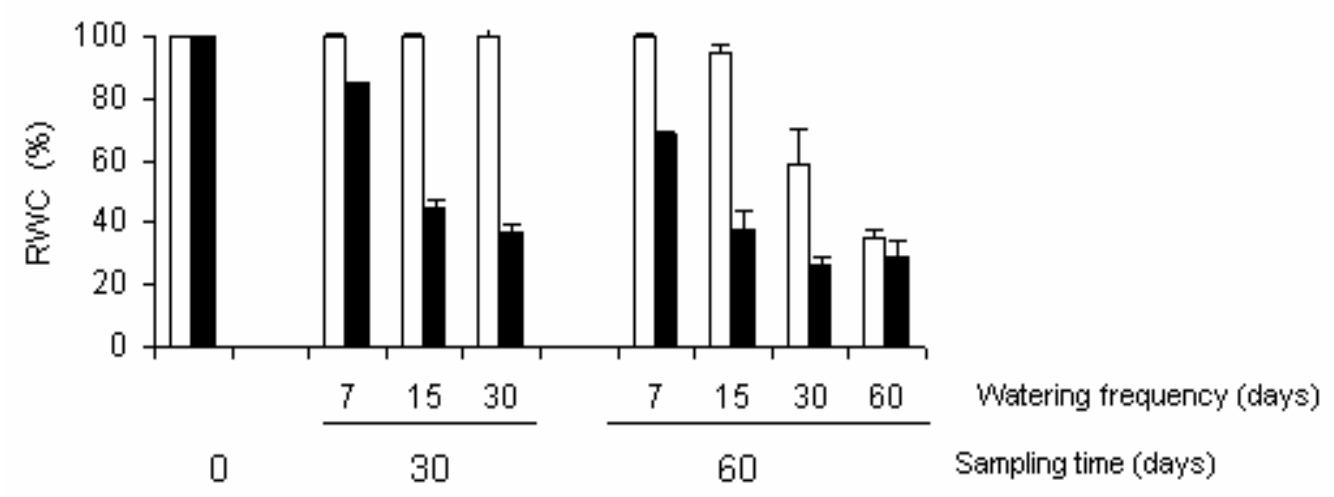

Figure 1 - Water content in soil ( $\square$ ) and relative water content in rhizophores ( $\square$ ) of V. herbacea under different watering treatments. Bars represent $1 \mathrm{x}$ standard error.
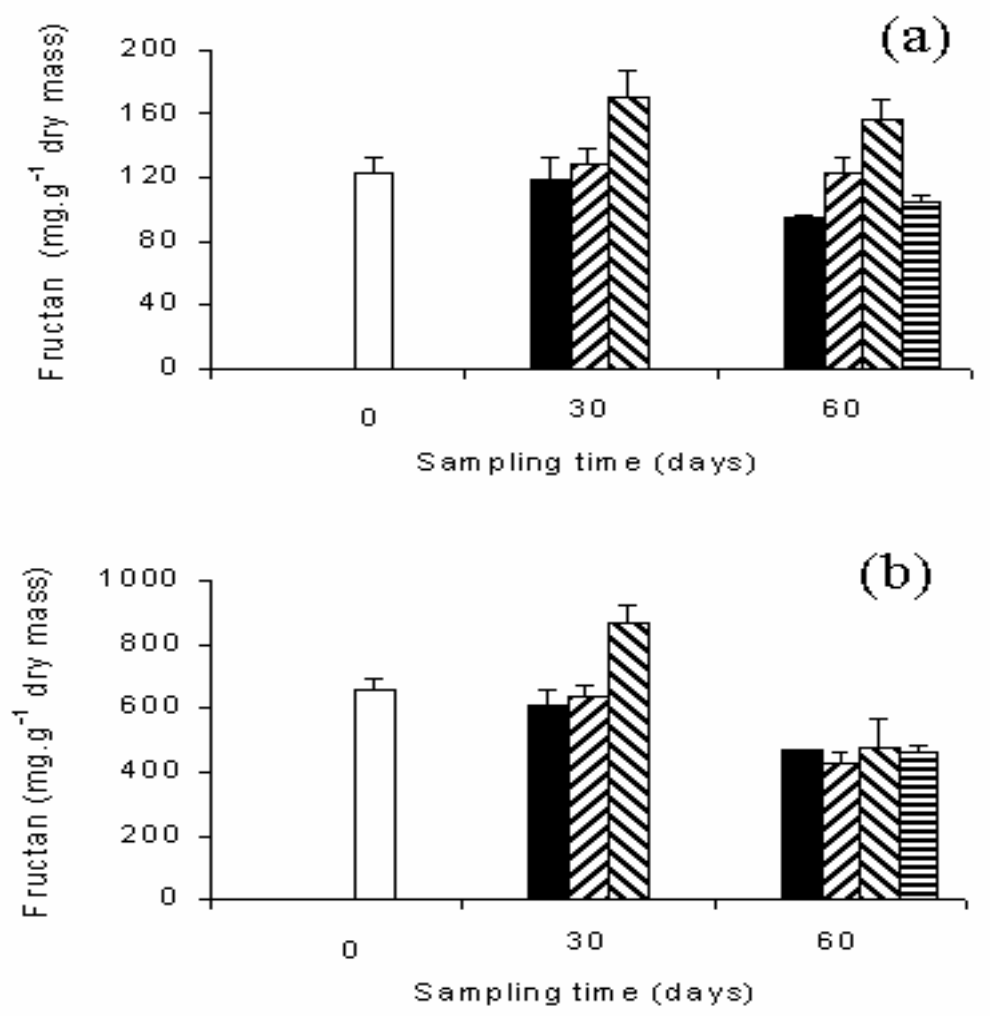

Figure 2 - Contents of fructo-oligosacharides (a) and fructo-polysacharides (b) in rhizophores of intact plants of $V$. herbacea under different watering frequency/ $(7(\mathbf{\square}), 15(\square), 30(\mathbb{\nabla})$ and 60 (目) days). Samples were taken at $0(\square)$ and after 30 and 60 days. Bars represent $1 \mathrm{x}$ standard error. 
Table 1 - Quantification of glucose, fructose and sucrose in rhizophores of plants of Vernonia herbacea under different watering treatments.

\begin{tabular}{ccccc}
\hline & & \multicolumn{3}{c}{ Sugar $\left(\boldsymbol{\mu g} . \mathbf{~ m g}^{-1} \mathbf{d r y}\right.$ mass) * } \\
\cline { 3 - 5 } Watering & $\begin{array}{c}\text { Sampling } \\
\text { Time (days) }\end{array}$ & Glucose & Fructose & Sucrose \\
\hline- & 0 & 7.98 & 15.28 & 8.33 \\
7 & 30 & 7.10 & 12.39 & 6.98 \\
7 & 60 & 1.19 & 10.01 & 5.80 \\
15 & 30 & 7.84 & 15.26 & 6.40 \\
15 & 60 & 4.12 & 19.91 & 8.73 \\
30 & 30 & 5.87 & 28.60 & 14.87 \\
30 & 60 & 3.14 & 20.40 & 10.33 \\
60 & 60 & 1.87 & 14.98 & 11.75 \\
\hline
\end{tabular}

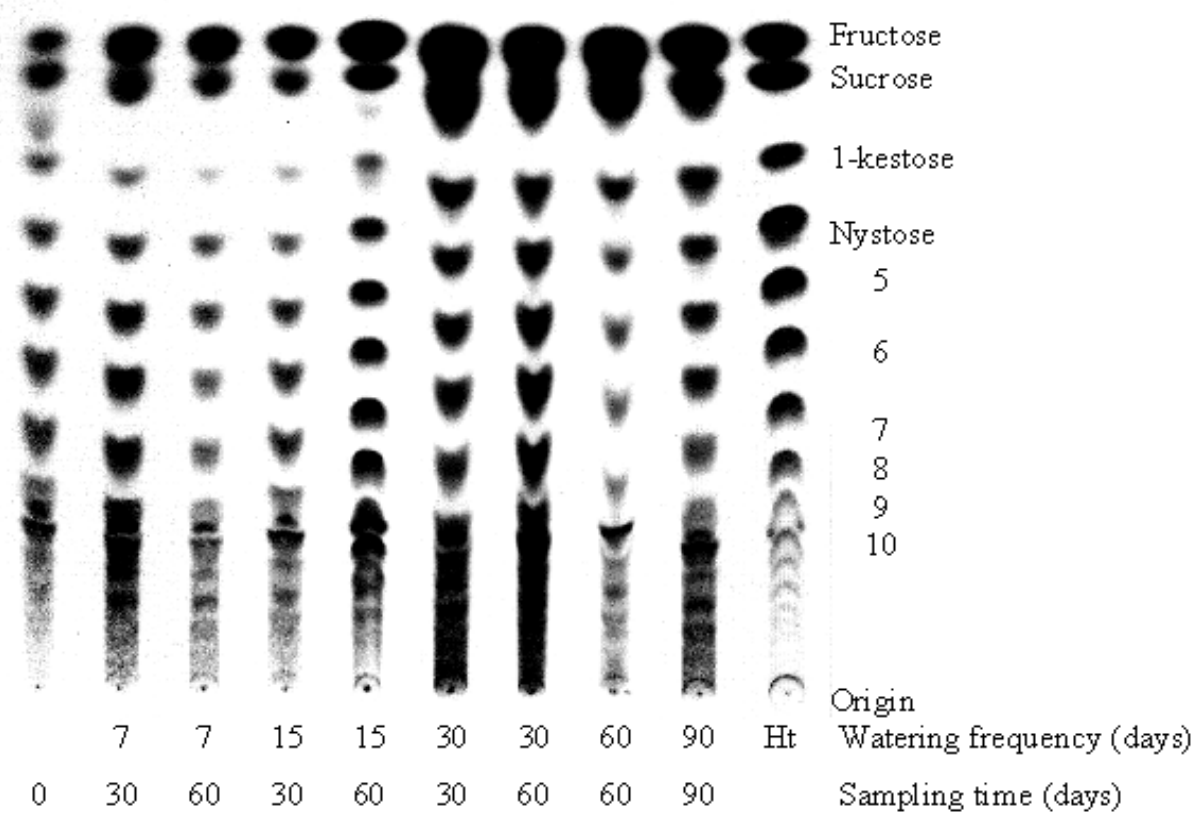

Figure 3 - TLC of fructo-oligosacharides present in rhizophores of intact plants of $V$. herbacea under different watering treatments. Numerals 5-10 mark the mobilities of fructooligosacharides of degree of polymerization 5-10. Each lane contains fructose equivalent to a fixed dry mass value. $\mathrm{Ht}$ - fructo-oligosaccharides from tubers of Helianthus tuberosus.

After 60 days without water, rhizophores exhibited a reduction in DP $3-14$ fructans and a consequent increase in the proportions of fructose and sucrose (Fig. 3). Quantification of glucose, fructose and sucrose by HPAEC/PAD analysis confirmed the increase of fructose and sucrose in plants watered every 30 days and sampled at 30 and 60 days (Table 1).

HPAEC/PAD profile of fructo-polysaccharides (Fig. 4) indicated that the relative mean molecular mass (Mr) of polymers increased in plants without irrigation for 60 days, possibly due to depolymerization of fructans of intermediate molecular size. Indeed, HPAEC/PAD profiles showed that peaks corresponding to those molecules, still clearly present in plants without water for 30 days (Fig. 4a,b) were markedly reduced in plants without irrigation for 60 days (Fig. 4c). In these groups of plants, the mean degree of polymerization changed from an initial 28 to 36 , as determined by gel permeation chromatography. After thirty days of water 
suspension a decrease in the average leaf number, leaf area and in the fresh mass of the aerial organs were clearly observed (Table 2 ).

In a short-term experiment, apical fragments of rhizophores were kept dry for five days when water was again supplied. Comparing the amounts of fructans present in the oligosaccharide and polysaccharide fractions (Fig. 5), higher values of oligosaccharides were found in treated fragments when compared to watered ones (Fig. 5a). Oppositely, higher values of polysaccharides were found in control fragments (Fig. 5b). Similar results were found when fructan contents were expressed on a dry mass basis.

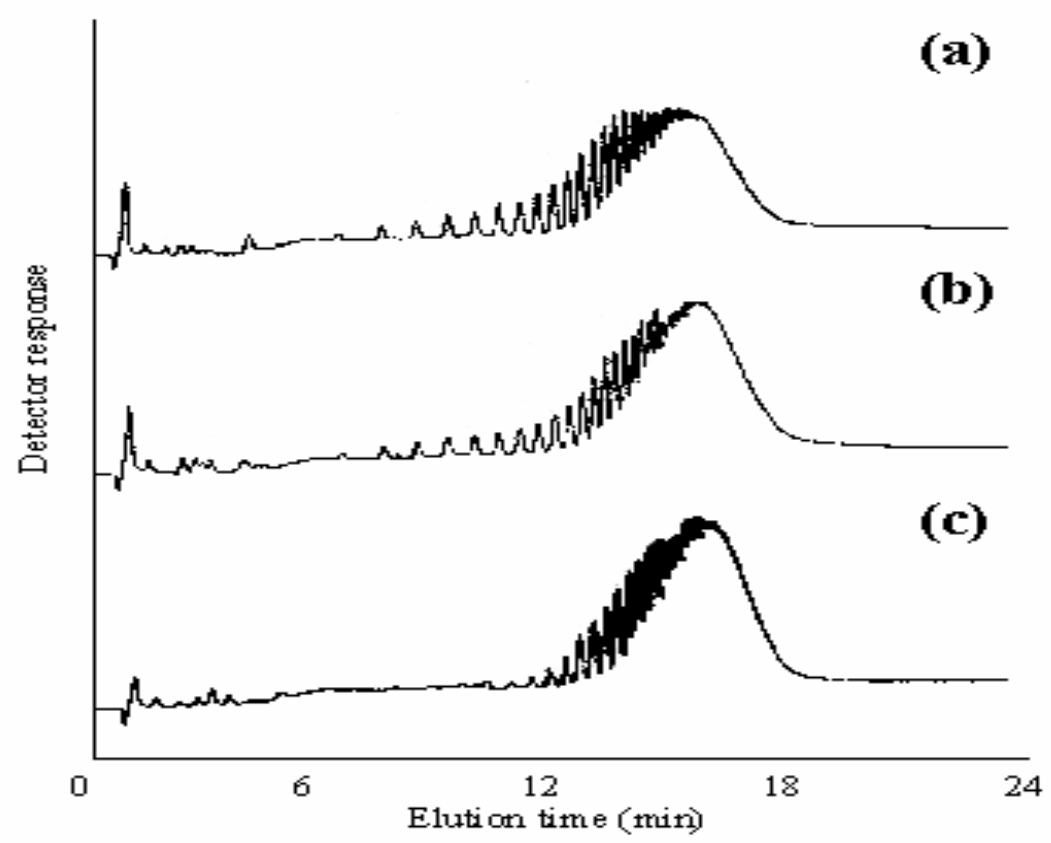

Figure 4 - HPAEC/PAD profiles of fructo-polysaccharides from rhizophores of plants of $V$. herbacea at time zero (a) and after 30 (b) and 60 (c) days without irrigation.

Table 2 - Average leaf number and area and fresh mass of aerial organs of plants of Vernonia herbacea under different watering treatments

\begin{tabular}{ccccc}
$\begin{array}{c}\text { Watering } \\
\text { Frequency (days) }\end{array}$ & $\begin{array}{c}\text { Sampling } \\
\text { Time (days) }\end{array}$ & $\begin{array}{c}\text { Leaf } \\
\text { Number }\end{array}$ & $\begin{array}{c}\text { Leaf } \\
\text { Area }\left(\mathbf{c m}^{2}\right)\end{array}$ & $\begin{array}{c}\text { Fresh } \\
\text { Mass (g) }\end{array}$ \\
\hline 0 & 0 & 13.0 & 9.2 & 6.2 \\
7 & 30 & 13.7 & 7.7 & 2.9 \\
7 & 60 & 18.2 & 6.5 & 4.6 \\
15 & 30 & 10.5 & 5.0 & 3.5 \\
15 & 60 & 12.0 & 4.4 & 0.7 \\
30 & 30 & 3.3 & 2.5 & 0.9 \\
30 & 60 & 0.0 & 0.0 & 0.9 \\
60 & 60 & 0.0 & 0.0 & \\
\hline
\end{tabular}



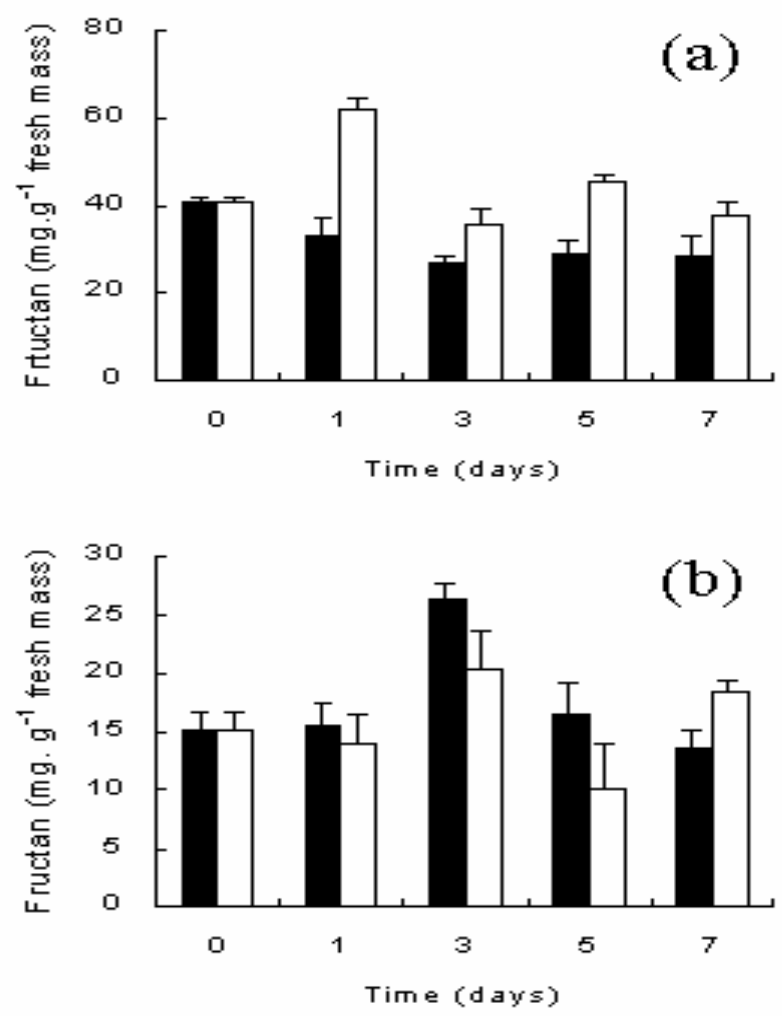

Figure 5 - Contents of fructo-oligosaccharides (a) and fructo-polysaccharides (b) in fragments of rhizophores of $V$. herbacea kept dry $(\square)$ and watered (ם). Droughted apices were rewatered after the fifth day of analysis.

HPAEC/PAD analyses of the oligosaccharides (Fig. 6) showed an increase in the proportions of monosaccharides and DP 4-10 fructans in treated tissues when compared to control on the first day of the experiment.

A similar profile of fructo-oligosaccharides was observed in control tissues five days after excision. Upon rewatering, the oligosaccharide profile in treated tissues was re-established showing proportions similar to those observed at the beginning of the experiment (Fig. 6).
Similar results were observed on TLC analyses of oligosaccharides from treated and control tissues (data not shown).

Relative water content was reduced in treated tissues 24 hours after excision and kept low throughout the period of water suppression. Upon rewatering, the water content was reestablished in these tissues. In control fragments, the water content remained unchanged throughout the experiment (Fig. 7). 


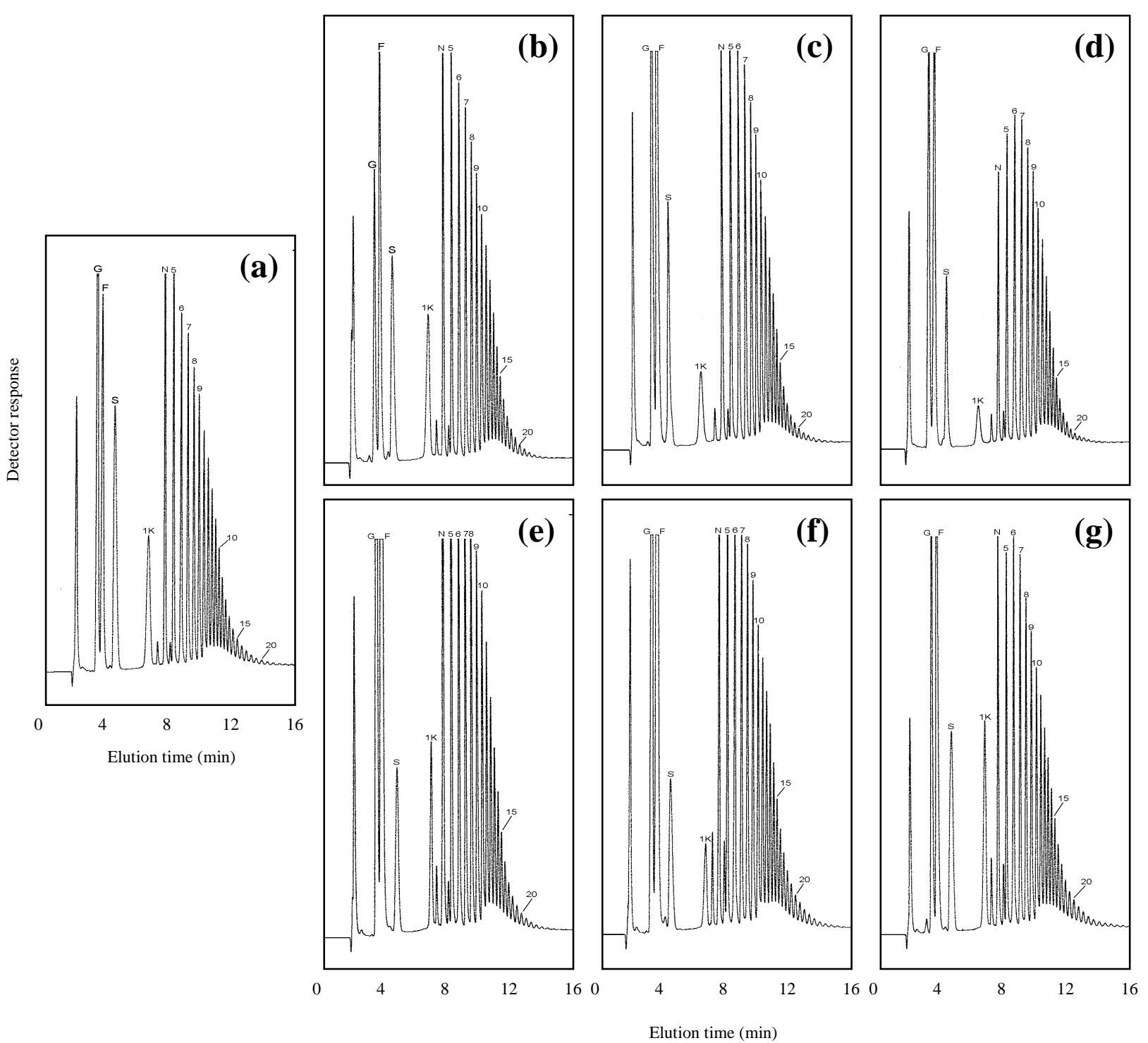

Figure 6 - HPAEC/PAD profiles of fructo-oligosaccharides present in fragments of rhizophores of $V$. herbacea. Time zero (a), watered rhizophores on days 1, 5 and 7 (b, c, d, respectively) and droughted rhizophores on days 1,5 (e, f, respectively) and after rewatering (g). G glucose, $\mathrm{F}$ - fructose, $\mathrm{S}$ - sucrose, $1-\mathrm{K}$ - 1-kestose, $\mathrm{N}$ - nystose. Numerals 5-20 identify the saccharides of DP 5-20.

\section{DISCUSSION}

Many plants, mainly those of the Asteraceae and Poaceae families which can tolerate periods of drought or low temperatures during their life cycle, accumulate fructans (Eagles, 1967), suggesting that these substances could act as cryoprotectants (Pontis and Del Campillo, 1985; Hendry, 1987) and osmotic regulators in plants subjected to water deficiency (Hendry 1993; Van den Ende, et al.1998). In Vernonia herbacea, which is naturally exposed to mild winter temperatures and water deficit in the soil, it has been shown that low temperatures (minimum $5{ }^{\circ} \mathrm{C}$ ) do not seem to interfere specifically with the seasonal pattern of fructan metabolism (Dias-Tagliacozzo et al., 
1999). In the present work, it has been shown that water deficit in the soil is associated with changes in the physiology of the plant and in fructan metabolism. Such changes included reduction of leaf area and leaf number (Table 2) and increase in fructose and sucrose and in the ratio oligo- to polysaccharide in the underground storage organ (Figs. 2 and 3). Similar results on leaf growth were reported by Thomas (1991) for Lolium perenne under drought treatments. These observations were accompanied by an increase in soluble carbohydrate, mainly DP > 5 fructans.

The enhancement in sugar concentration, mostly represented by fructans (Carvalho and Dietrich, 1993), in rhizophores of $V$. herbacea under drought treatments could be partly due to the translocation of photosynthates from the slow growing and senescing aerial parts providing a mechanism of osmoregulation and consequently, the maintenance of cell turgor under low water soil condition. The observed increases in fructose concentration and in the ratio of oligo- to polysaccharides were indicative of partial hydrolysis of fructans in response to the induced water deficit and also to the involvement of fructan exohydrolase (FEH) and fructan:fructan fructosyl transferase (FFT), contributing to drought resistance in these plants.

The effect of water restriction on these enzymes, leading to changes in the proportions of oligo- and polysaccharides could also be suggested from data of the experiment with excised rhizophores. As shown in Fig. 5, fragments subjected to drought presented always higher amounts of oligosaccharide and lower amounts of polysaccharides when compared to control, watered fragments. The analyses of the fructooligosaccharides by HPAEC/PAD provided evidence that drought promoted the activities of FFT and FEH, as observed by the quick increase in monosaccharides and DP 4-10 fructans. Similar changes were observed in control fragments with a four-day delay (Fig. 6). The increase in mono- and oligosaccharides in rhizophores of $V$. herbacea under drought could be compared to the increase in mono- and disaccharides reported for feeder roots of chicory during PEG-induced osmotic stress (Van den Ende et al., 1998).

The dry season in the cerrado lasts for three months in average, coinciding with winter (De Vuono et al., 1986). During this period, total fructans increase in the rhizophores of $V$. herbacea growing in the cerrado, reflecting a strong sink activity of these organs (Carvalho and Dietrich, 1993).

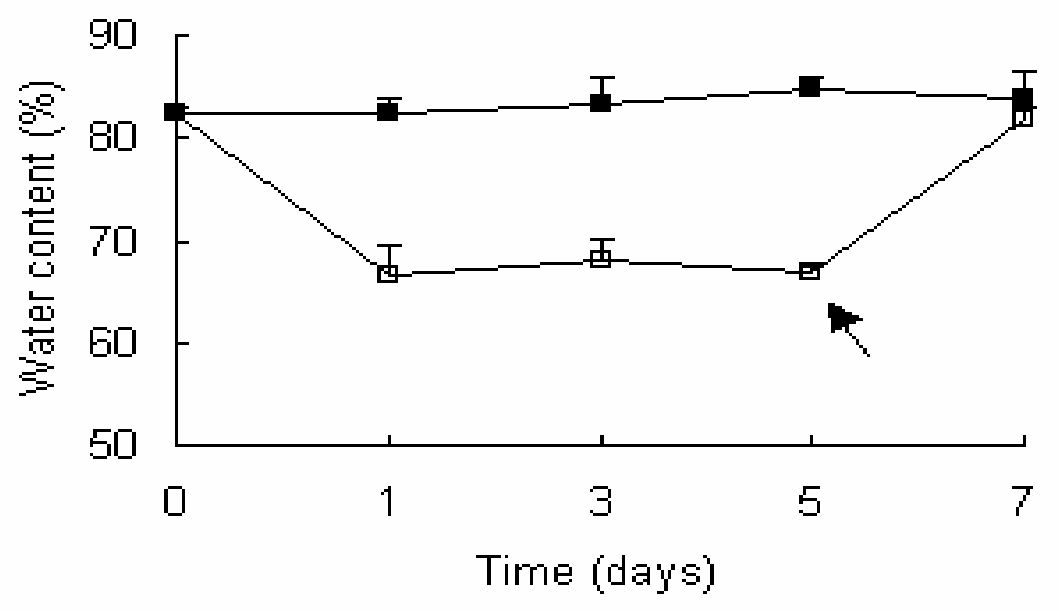

Figure 7 - Water content in fragments of rhizophores of $V$. herbacea kept dry ( $\square$ ) and watered ( $\mathbf{\square})$. Arrow indicates rewatering of droughted fragments.

These authors reported that the TLC profile of fructo-oligosaccharides showed an increase in the proportion of intermediate size oligosaccharides without a corresponding increase in fructose 
suggesting the involvement of fructosyl transferases more than hydrolases during winter. In the present investigation, the increase in fructose concentrations and in the ratio of oligo- to polysaccharides suggested that under extreme drought conditions, hydrolases besides fructosyl transferases could also be involved in fructan mobilisation. Data shown in this paper indicate that the resistance of $V$. herbacea to water restriction is related to changes in fructan metabolism favouring water retention in the rhizophores.

\section{ACKNOWLEDGEMENTS}

The authors would like to thank Fundação de Amparo à Pesquisa do Estado de São Paulo (FAPESP) for financial support (91/3588-8 and 98/05124-8). M.A.M.Carvalho, R.C.L.FigueiredoRibeiro and S.M.C. Dietrich are research fellows of Conselho Nacional de Desenvolvimento Científico e Tecnológico (CNPq).

\section{RESUMO}

A vegetação herbácea do cerrado brasileiro apresenta sistemas subterrâneos ricos em frutanos e estacionalmente expostos à restrição hídrica. A fim de avaliar o envolvimento dos frutanos na tolerância à dessecação foram conduzidos experimentos utilizando plantas intactas e fragmentos de rizóforos de Vernonia herbacea. $\mathrm{O}$ conteúdo de água nos rizóforos de plantas intactas foi mantido por 30 dias, quando as plantas foram molhadas a cada 7 ou 15 dias, sendo que as plantas permaneceram vivas até 60 dias sem água. $\mathrm{O}$ conteúdo total de frutanos, a razão oligo/polissacarídeos e a massa molecular média dos polissacarídeos nessas plantas aumentaram, indicando haver ocorrido despolimerização de moléculas com tamanho intermediário das cadeias. Nos fragmentos apicais de rizóforos submetidos à dessecação, os oligossacarídeos aumentaram em relação aos polissacarídeos, um dia após a excisão dos tecidos tratados. Essas alterações foram facilmente detectadas através dos perfis de oligossacarídeos analisados por HPLC, nos quais a proporção de frutose livre e de frutanos com GP 4 - 10 aumentou acentuadamente. Os resultados indicam que o metabolismo de frutanos está envolvido na tolerância à dessecação de Vernonia herbacea.

\section{REFERENCES}

Andrews, P. (1965), The gel filtration behaviour of proteins related to their molecular weights over a wide range. Biochem. J., 96, 595-606.

Carvalho, M. A. M. (1991), Variações no conteúdo e composição de frutanos em rizóforos de Vernonia herbacea (Vell) Rusby. PhD Thesis, State University of Campinas, Brazil.

Carvalho, M. A. M.; Dietrich. S. M. C. (1993), Variation in fructan contents in the underground organs of Vernonia herbacea (Vell.) Rusby at different phenological phases. New Phytol., 123, 735740.

Carvalho, M. A. M.; Zaidan, L. B. P. and Dietrich, S. M. (1997), Growth and fructan content of plants of Vernonia herbacea (Asteraceae) regenerated from rhizophores. New Phytol., 136, 153-161.

De Vuono, Y. S.; Batista, E. A. and Funari, F. L. (1986), Balanço hídrico na área da Reserva biológica de MogiGuaçú, São Paulo-Brasil. Hoehnea, 13, 73-85.

Dias-Tagliacozzo, G. M.; Figueiredo-Ribeiro, R. C. L.; Carvalho, M. A. M. and Dietrich, S. M.C. (1999), Fructan variation in the rhizophores of Vernonia herbacea (Vell.) Rusby, as influenced by temperature. Revta bras. Bot., 22, 267-273.

Eagles, G. F. (1967), Variation in the soluble carbohydrate content of climate races of Dactylis glomerata (cocksfoot) at different temperatures. Ann. Bot., 31, 350- 356.

Hendry, G. A. F. (1987), The ecological significance of fructan in a contemporary flora. New Phytol., 106, 201-216.

Hendry, G. A. F. (1993), Evolutionary origins and natural functions of fructans. A climatological, biogeographic and mechanistic appraisal. New Phytol., 123, 3-14.

Hendry, G. A. F. and Wallace, R. K. (1993), The origin, distribution and evolutionary significance of fructans. In: Suzuki, M. and Chatterton, J. N. (eds.). Science and Technology of fructans. Boca Raton : CRC Press. pp. 119-139.

Jermyn, M. A. (1956), A new method for the determination of ketohexoses in presence of aldohexoses. Nature, 177, 38-39.

Kanaya, K. I.; Chiba, S. and Shimomura, T. (1978), Thin-layer chromatography of linear oligosaccharides. Agric. Biol. Chem., 42, 1947-1948.

Menezes, N. L.; Muller, C. and Sajo, M. G. (1979), Um novo e peculiar tipo de sistema subterrâneo em espécies de Vernonia da Serra do Cipó (Minas Gerais, Brasil). Bol. Bot. Univ São Paulo, 7, 33-38.

Pilon-Smits, E. A. H.; Ebskamp, M. J. M.; Paul, M. J.; Jeuken, M. J. W.; Weisbeek, P. J. and Smeekens, S. 
C. M. (1995), Improved performance of transgenic fructan-accumulating tobacco under drought stress. Plant Physiol., 107, 125-130.

Pilon-Smits, E. A. H.; Terry, N.; Sears, T. and Van Dun, K. (1999), Enhanced drought resistance in fructan-producing sugar beet. Plant Physiol. Biochem., 37, 313-317.

Pollock, C. J. (1986), Fructans and the metabolism of sucrose in vascular plants. New Phytol., 104, 1-24.

Pollock, C. J. and Jones, T. (1979), Seasonal patterns of fructan metabolism in forage grasses. New Phytol., 83, 8-15.

Pontis, H. G. and Del Campillo, E. (1985), Fructans. In: Dey, P. M. and Dixon, R. (eds). Biochemistry of storage carbohydrates in green plants. London : Academic Press. pp. 205-227.

Puebla, A. F.; Salerno, G. L. and Pontis, H.G. (1997), Fructan metabolism in two species of Bromus subjected to chilling and water stress. New Phytol., 136, 123-129.

Shiomi, N. (1993). Structure of fructo-polysaccharide (asparagosin) from roots of asparagus (Asparagus officinalis L.). New Phytol., 123, 263-270.

Spollen, W. G. and Nelson, C. J. (1994). Response of fructan to water deficit in growing leaves of tall fescue. Plant Physiol., 106, 329-336.

Tertuliano, M. F. and Figueiredo-Ribeiro, R. C. L. (1993), Distribution of fructose polymers in herbaceus species of Asteraceae from the cerrado. New Phytol., 123, 741-749.

Thomas, H. (1991), Accumulation and consumption of solutes in swards of Lolium perenne during drought and after rewatering. New Phytol., 118, 35-48.
Van den Ende, W.; Moors, S.; Van Hoenacker, G. and Van Laere A. (1998), Effect of osmolytes on the fructan pattern in feeder roots produced during forcing of chicory (Cichorium intybus L.). J. Plant Physiol., 153, 290-298.

Vijn, I.; van Dijken, A.; Sprenger, N.; van Dun, K.; Weisbeek, P.; Wiemken, A. and Smeekens, S. (1997), Fructan of the inulin neoseries is synthesized in transgenic chicory plants (Cichorium intybus L.) harbouring onion (Allium cepa L.) fructan:fructan 6G-fructosyltransferase. Plant J., 11, 387-398.

Wagner, W.; Keller, F. and Wiemke, A. (1983), Fructan metabolism in cereals induction in leaves and compartmentation in protoplasts and vacuoles. Zeitschrift Pflanzenphysiol., 112, 359-372.

Wiemken, A.; Frehner, M.; Keller, F. and Wagner, W. (1986), Fructan metabolism, enzymology and compartmentation. Curr. Topics Plant Biochem. and Physiol., 5, 17-37.

Wise, C. S.; Dimler, R. J.; Davis, H. A. and Rist, C. E. (1955), Determination of easily hydrolyzable fructose units in dextran preparation. Analyt. Chem., 27, 33-36.

Received: July 22, 2002; Revised: December 26, 2002; Accepted: August 11, 2003. 